\title{
Heat Lump in Different Pavement Layer Using Ethylene Glycol as A Solar Heat Collector
}

\author{
Siti Hidayah Abu Talib ${ }^{1,}$, Syarifah Intan Najla Syed Hashim ${ }^{2}$, Salmia Beddu ${ }^{3}$, Anis Farhah Maidin ${ }^{4}$, Muhammad Salleh \\ Abustan \\ ${ }^{1}$ Lecturer, Faculty of Civil and Environmental Engineering, Universiti Tun Hussein Onn Malaysia, 86400 Parit Raja, Batu Pahat, Johor, \\ Malaysia. \\ ${ }^{2}$ Postgraduate Student, Faculty of Civil and Environmental Engineering, Universiti Tun Hussein Onn Malaysia, 86400 Parit Raja, Batu \\ Pahat, Johor, Malaysia. \\ ${ }^{3}$ Senior Lecturer, Civil Engineering Department, College of Engineering, Universiti Tenaga Nasional, Putrajaya Campus, Jalan IKRAM- \\ UNITEN, 43000 Kajang, Selangor, Malaysia. \\ ${ }^{4}$ Undergraduate Student, Faculty of Civil and Environmental Engineering, Universiti Tun Hussein Onn Malaysia, 86400 Parit Raja, Batu \\ Pahat, Johor, Malaysia.
}

\begin{abstract}
Due to the hot weather in Malaysia, several studies being carried out regarding solar energy harvesting and use as a noble renewable energy. Therefore, researchers start developing various methods to utilize sun's heat as a renewable source of energy. Solar energy has been always concern researchers to develop most effective, durable and cheap methods and materials to be used as solar energy collectors in road pavements. Therefore, this study was conducted to determine the maximum heat area using ethylene glycol. The study was involved the field monitoring of the six samples of asphalt slab with stainless steel pipe with ethylene glycol and empty pipe act as the controlled sample. The pipe was arranged in three different depths of $50 \mathrm{~mm}, 100 \mathrm{~mm}$ and $150 \mathrm{~mm}$ and keeping controlled the pipe diameter and the size of slab of $20 \mathrm{~mm}$ and $300 \mathrm{~mm} \times 300 \mathrm{~mm}$ respectively. These results show that the maximum heat extraction by the ethylene glycol was at a depth $150 \mathrm{~mm}$ which was $51.2^{\circ} \mathrm{C}$. The average percentage increments of the pipe with ethylene glycol for three days for pipe depth $50 \mathrm{~mm}$ was $71 \%$, while for pipe at depth $100 \mathrm{~mm}$ and $150 \mathrm{~mm}$ were $78 \%$ and $62 \%$ respectively. The ethylene glycol effect was more noticeable compare to the pipe without ethylene glycol and can store more heat. For the strength of pipe, the highest maximum load bearing capacity that can be supported by the stainless steel pipe was at depth $50 \mathrm{~mm}$ and the second highest was at a depth $100 \mathrm{~mm}$ while the third highest was at depth $150 \mathrm{~mm}$. So, the suitable depth to install the pipe with the consideration of both cases which was maximum heat gain and the maximum load that can be supported was at depth $50 \mathrm{~mm}$.
\end{abstract}

\section{Introduction}

Asphalt pavement as a solar collector was believed to be one of the most efficient techniques of harvesting solar energy by collecting solar radiations that hit the pavement throughout all day long and cause the pavement to contain amounts of heat energy which can be utilized and used for many purposes. In European countries, asphalt pavement as a solar collector is used for heating and melting the snow. The implementation of natural source of energy is more favourable due to its availability, environmental friendly and cost effective. Besides, asphalt collector is used for heating and cooling the buildings. However, high temperature in asphalt pavement also may lead to the global warming.

Solar energy is the primary energy source for all other forms of energy source distributed around the world. Road pavement is one of the largest solar thermal collector and storage system on land. It receives solar radiation all day and stores some of the energy from it. This energy is completely or partially dissipated to atmosphere by night time. An average temperature of an asphalt pavement can reach up to $60-70^{\circ} \mathrm{C}$ on hot day

\footnotetext{
a Corresponding author: hidayaht@uthm.edu.my
}

because of its excellent heat absorbing characteristic. The solar thermal energy collected by the asphalt pavement can be harvested by circulating fluid through it. A system that is designed for this purpose is called asphalt solar collector (ASC).

Renewable energy technologies are likely to become more important as other energy sources become depleted and the cost of power generation using fossil fuels rises. However, in most cases, renewable energy technologies require high initial investments that may deter potential users. Asphalt Solar Collector potentially offer a low-cost solution to sustainable and clean energy generation by using pavement infrastructure.

The water solvent in the pipes can absorb/reject heat to the pavement and store energy to in the pavement structure. A significant advantage of the system is that the pipes are installed within pavements that are already needed for structural reasons and need not to be specially constructed as the conventional thermal energy utilization systems such as solar panels. The ability of pavement to collect and/or store solar energy is a relatively new subject that is still at an early age of development. This research is in general to determine the maximum heat 
area in asphalt pavement by using steel pipe with ethylene glycol.

\subsection{Problem Statement}

In recent years, many researchers have studied the use of road pavements as an energy collector by presenting several technologies and methods. These studies focus on the use of heat collected from pavements to produce energy. Through asphalt, the aim is to develop a solar collector that can make the roads and parking lots a source of electricity or hot water as the pavement layers stay hot at night and can continue generating energy after the sun goes down, unlike traditional solar electric cells. In this method there is needed to occupy lands for solar farms and the solar system can be invisible if the researchers can convince the industry to change the way they are building roads pavements.

To harvest the maximum amount of solar heat, several studies have been carried out on road pavement as a solar collector system. Multi-layered pavement with a high porous middle layer to be used instead of solar collector with an installed pipe network [1]. However the thermal efficiency results were excellent, this result contrasted with the low flow rate level recorded during the experiment.

Therefore, solar collector in pavement is an alternative of green energy harvesting while solving the problem of renewable energy for fossil fuels and reducing the heat island effect on asphalt pavement. Figure 1 shows the proposed distribution of heat energy from solar pavement to the housing areas.

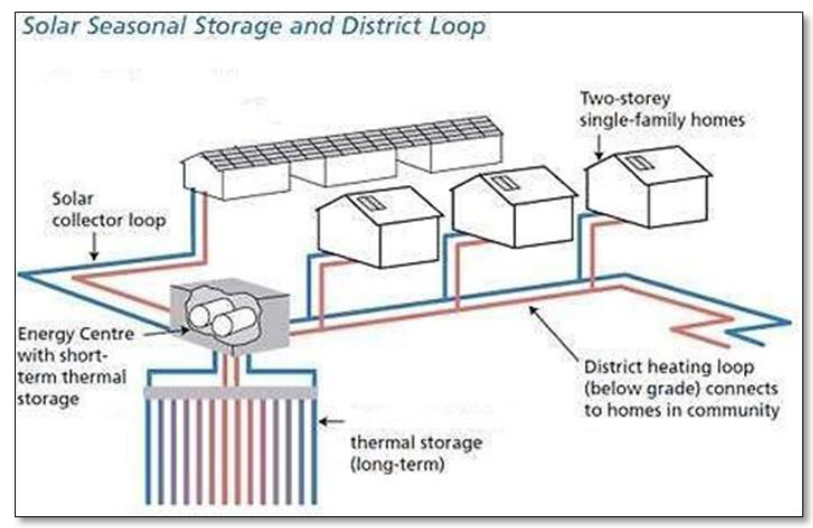

Figure 1: Solar pavement storage and distribution.

\subsection{Objectives of Study}

The aim of this study is to determine the optimum heat lump area in the pavement. There are two objectives of this study.

1. To determine the optimum depth using ethylene glycol in order to get maximum heat extraction.
2. To determine the strength of steel pipe to withstand loading from vehicles.

\section{Literature Review}

Several authors have developed methods to predict the asphalt temperatures because they will significantly affect the pavements where high temperatures can cause plastic deformations while lower temperatures can leads to damage by hardening [2].

Asphalt solar collectors consist of pipes embedded in the pavement with a circulating fluid inside. Solar radiation causes an increase in pavement temperature. Due to the temperature gradient between the fluid circulating through pipes and the pavement, a heat transfer process occurs from pavement to fluid which leads to a drop in pavement temperature and an increase in fluid temperature [3].

The temperature distribution of an asphalt pavement is affected directly by the thermal environment conditions to which it is exposed. The primary modes of heat transfer include incident solar radiation, thermal and long wave radiation between the asphalt pavement surface and the sky, convection due to heat transfer between the pavement surface and the fluid (air or water) that is in contact with the surface, conduction inside the pavement, and the radiation heat loss from surface Figure 2 shows the various heat transfer modes in a heat conducting asphalt pavement exposed to solar radiation.

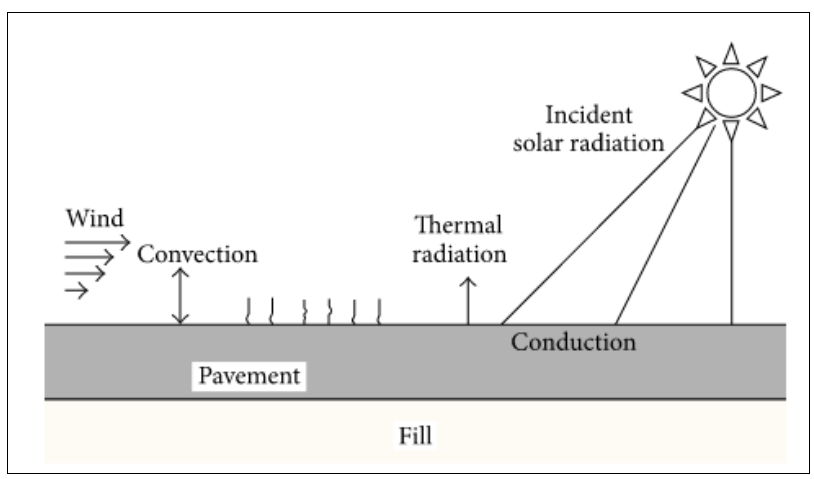

Figure 2: Schematic presentation of heat transfer mode of asphalt pavement [4].

A numerical simulation was developed by Wang et al. in which a model of an asphalt collector with a net of rubber pipes in its middle layer was used to predict the thermal response of these devices in order to determine which parameters were critical in the behavior of an asphalt collector [5]. Besides that, $\mathrm{Wu}$ et al. had investigated the process of extracting thermal energy from asphalt slabs with $\mathrm{u}$-shaped metal tubes inside. It was proven that the circulating water can reduce the surface temperature of the asphalt pavement thus reducing the risk of permanent deformation and the urban heat island effect [6]. 
Heat exchangers are normally used only for the transfer and useful elimination or recovery of heat without an accompanying phase change. The fluids on either side of the barrier are usually liquids, but they may also be gases such as steam, air, or hydrocarbon vapors; or they may be liquid metals such as sodium or mercury. Fused salts are also used as heat-exchanger fluids in some applications. The exchangers are used to recover heat between two streams in a process; these fluids may be single compounds or mixtures [7].

The characteristics required for the circulating fluid are: high specific heat, stability in the collector operating temperature range, compatibility with pipes, abundance and low cost. Water is one of the best fluids for systems operating at low temperatures (range from $25^{\circ} \mathrm{C}$ to $90^{\circ} \mathrm{C}$ ) such as asphalt solar collectors [8], but the solidification temperature must be less than the minimum temperature expected at the collector. For this reason mixtures of water and antifreeze are generally used.

\section{Materials and Methods}

Experiments began with the preparation of samples that was done according to the standard specifications of pavement from public work department (JKR) before the collection and analysis of data. This chapter will describes the process throughout the research and necessary steps to be studied from the beginning of the research until the laboratory testing to analyze the expected results of the study.

After identifying the materials and apparatus needed, field experiment and laboratory testing will be conducted in Highway Laboratory in UTHM. The results obtained from the observation and laboratory testing will be recorded and analyzed. Total 6 models of asphalt pavement are designed where the heat exchanger which is steel pipes are installed in different depth. Different depths of models with steel pipes analyzed in this study are shown in Table 1.

Table 1: Number of samples analysed in the study

\begin{tabular}{|c|c|c|c|}
\hline No. & $\begin{array}{c}\text { Size of model } \\
(\mathrm{mm})\end{array}$ & $\begin{array}{c}\text { Depth } \\
(\mathbf{m m})\end{array}$ & Steel Pipe \\
\hline 1. & \multirow{6}{*}{$300 \times 300$} & $50 \mathrm{~mm}$ & \multirow{3}{*}{ Empty } \\
\hline 2. & & $100 \mathrm{~mm}$ & \\
\hline 3. & & $150 \mathrm{~mm}$ & \\
\hline 4. & & $50 \mathrm{~mm}$ & \multirow{3}{*}{$\begin{array}{l}\text { Ethylene } \\
\text { glycol }\end{array}$} \\
\hline 5. & & $100 \mathrm{~mm}$ & \\
\hline 6. & & $150 \mathrm{~mm}$ & \\
\hline
\end{tabular}

\subsection{Sample preparation}

The sample preparation was conducted in Highway Laboratory at Universiti Tun Hussein Onn Malaysia. Six (6) physical models (pavement) are prepared in different pipe depth. 3 models were installed with empty steel pipe at different depths while the other 3 models were installed with steel pipes and ethylene glycol as a heat exchanger fluid at different depths.
The preparation of pavement is following Public Work Department (JKR) standard specifications. Steel pipes are inserted in the pavement as the heat exchanger pipe. In order to find out the temperature variation within the asphalt pavement and the amount of energy extracted by pavement, the models are placed outdoor with direct sunlight and connected to the data logger. The pavement structure has a dimension of $300 \mathrm{~mm} \times 300 \mathrm{~mm}$ with a total depth of $150 \mathrm{~mm}$. In the asphalt pavement structure, studies are conducted by varying the pipe depth $(50 \mathrm{~mm}$, $100 \mathrm{~mm}$ and $150 \mathrm{~mm}$ ) from the bottom of pavement layers, keeping the pipe diameter fixed at $15 \mathrm{~mm}$ diameter as shown in Figure 3, 4 and 5.

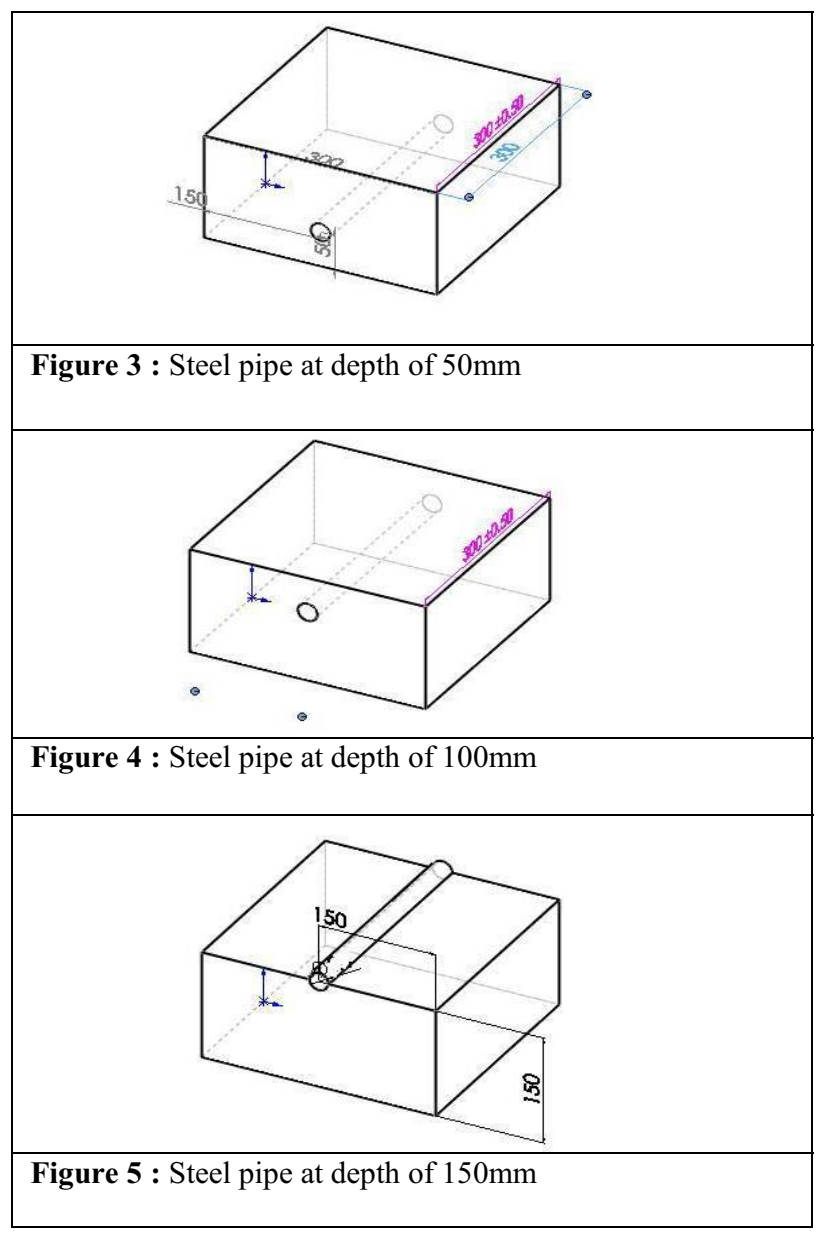

\subsection{Field experiment}

This research was conducting a small-scale field test under real atmospheric conditions. The field test setup consists of asphalt pavement, heat exchanger pipe which is empty steel pipes and steel pipes filled with ethylene glycol, source of heat from sun, thermocouples and a data logger for data collection.

Thermocouples will be inserted in the pavement and connected to the data logger to measure the temperature of heat absorbed in pavement. The samples will be left under the sun for 24 hours in 3 days. The data will be recorded every 5 minutes and transmitted directly to the data logger. Figure 6 shows the arrangement of asphalt pavement solar collector for field testing in 
UTHM with empty pipe and pipe filled with water solvent.

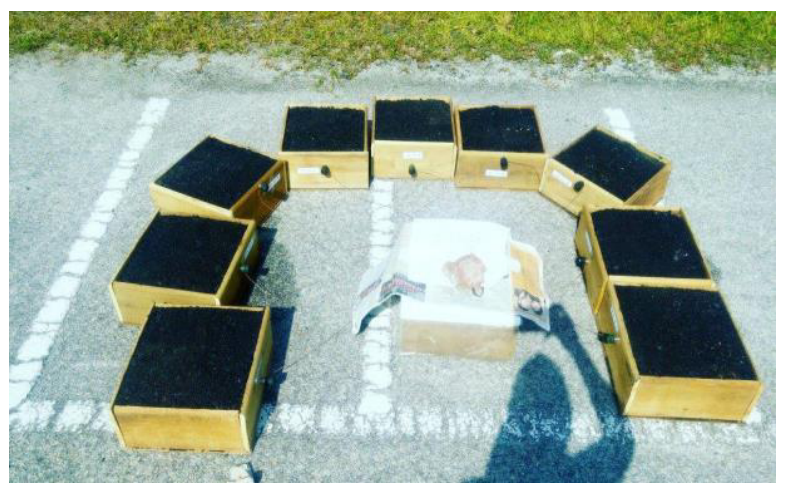

Figure 6 : Arrangement of models connected with data logger in field experiment

\subsection{Laboratory testing}

Laboratory testing for structural analysis is done to determine the maximum strength of steel pipe in pavement to withstand loading. Loading will be applied on samples by using California Bearing Ratio (CBR) machine. Three (3) samples were prepared by following the JKR standard specifications and compacted in mould before conducting the strength test. Samples will consist of steel pipe at 3 different depths which are at depth of $50 \mathrm{~mm}, 100 \mathrm{~mm}$ and $150 \mathrm{~mm}$. Figure 7 shows the samples of asphalt pavement prepared for laboratory testing.

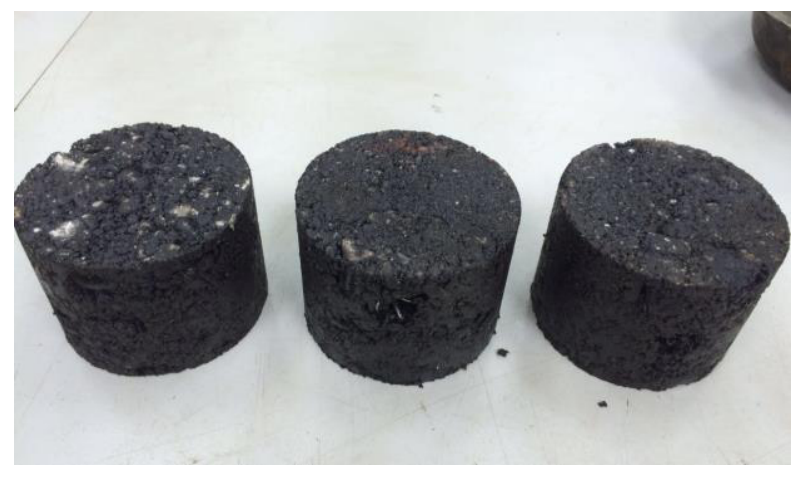

Figure 7 : Laboratory samples of asphalt pavement

The California Bearing Ratio (CBR) test is a simple strength test by applying load to a small penetration piston at a rate of $1.3 \mathrm{~mm}$ per minute and recording the total load of penetration applied on samples. This test was first developed by the California Division of Highway as a method for evaluating the strength of soil subgrade and other flexible pavement materials.

This test can be performed in the laboratory on prepared samples or in-situ on location. The CBR test is essentially used to evaluate the strength of pavement. The loading device on CBR machine having a capacity of $50 \mathrm{kN}$ and equipped with a movable head or base that travels at a uniform rate of $1.3 \mathrm{~mm}$ per minute for use in forcing the penetration plunger to the sample. The machine's digital display provides the ability to monitor test data as well as the ability to see a test peak value and the maximum loading. Figure 8 shows the California Bearing Ratio (CBR) machine in Highway Laboratory, UTHM.

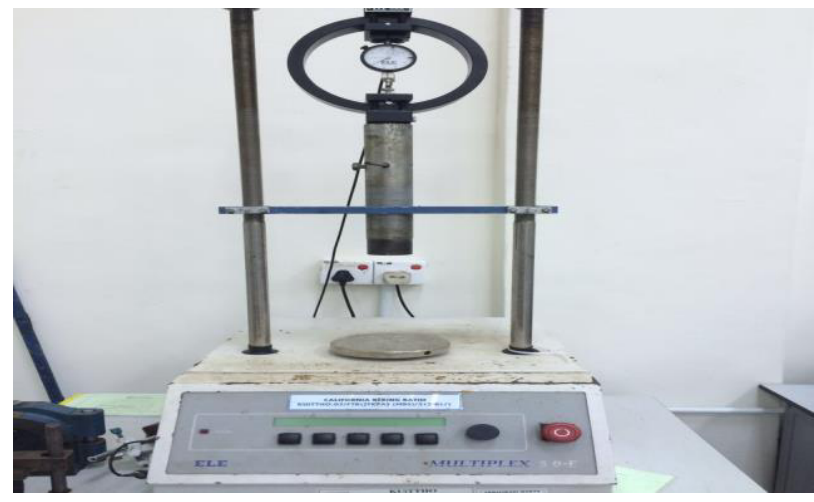

Figure 8 : California Bearing Ratio (CBR) machine

\section{Results and Discussion}

The field experiments and laboratory testing had been conducted and the data had been recorded for analysis. The result had been analyzed in order to achieve the research objectives which are to obtain maximum heat extraction of solar collector in different pipe depth and to determine the maximum strength of steel pipe to withstand loading.

The experimental setup was placed outside for exposure to the sun. In this experiment, the pavement is exposed to the sun and left outside for 24 hours from approximately $12 \mathrm{AM}$ to $12 \mathrm{AM}$ the next day. Data for the heat absorption in asphalt pavement was recorded every 5 minutes by using data logger. Then, the result were analyzed and graph were plotted to observe at which depth of pavement $(50 \mathrm{~mm}, 100 \mathrm{~mm}, 150 \mathrm{~mm})$ have the maximum heat extraction. The field experiment was conducted under Batu Pahat, Johor climate condition and the location of study is in UTHM area.

\subsection{Thermal performance of asphalt layer}

The asphalt behavior for surface temperature is shown in Figure 9. The data were collected for 3 days continuously. Temperature was measured on both sunny and rainy days, which represent the real weather condition. The data logger was neither distracted nor shut off during the experiment.

The temperature was noticed to be more affected at the period between $12 \mathrm{pm}$ to $4 \mathrm{pm}$ everyday where the maximum sun, heat radiations are more likely to hit the surface of the pavement. 


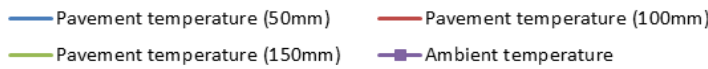

$\longrightarrow$ Pavement temperature $(150 \mathrm{~mm}) \rightarrow$ Ambient temperature

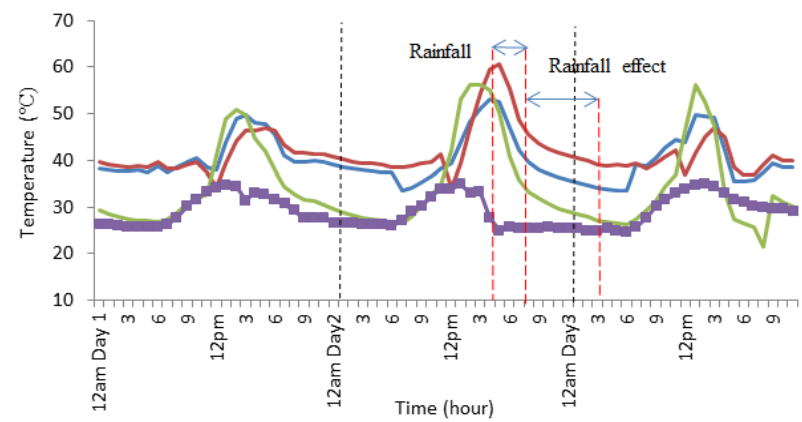

Figure 9 : Thermal performance of pavement temperature and ambient temperature in different depths for 3 days

Temperature was low in the morning due to low solar radiation and resulting in less energy being absorbed by ethylene glycol in steel pipe. During daytime, solar radiation is high, and the ethylene glycol in steel pipe could absorb a large amount of thermal energy, resulting in a large degree of temperature for heat extraction.

The occurrence of rainfall during the experiment on Day 2 had affected the temperature of pavement surface. Further investigation showed that maximum pavement temperature is lowered until the next day after rainfall and the rainfall effect had altered the temperature of pavement surface which is up to $58.9^{\circ} \mathrm{C}$ (after rainfall) from $42.5^{\circ} \mathrm{C}$ (before rainfall). It shows that rainfall plays a major role as a cooling agent to reduce the surface temperature of asphalt pavement.

\subsection{Efficiency of ethylene glycol as a heat collector}

Table 2 shows the temperature difference of maximum temperature at pavement in different layers with ethylene glycol, empty pipe and ambient temperature for 3 days.

Table 2 : Percentage of heat increment in pavement surfaces

\begin{tabular}{|c|c|c|c|c|c|c|c|}
\hline \multirow{3}{*}{ Day } & \multirow{3}{*}{$\begin{array}{l}\text { Depth } \\
\text { (mm) }\end{array}$} & \multicolumn{4}{|c|}{ Temperature $\left({ }^{\circ} \mathrm{C}\right)$} & \multicolumn{2}{|c|}{ \% Increment } \\
\hline & & \multicolumn{2}{|c|}{ Ambient } & \multicolumn{2}{|c|}{ Pavement } & \multirow{2}{*}{$\begin{array}{l}\text { Pipe with } \\
\text { ethylene } \\
\text { glycol }\end{array}$} & \multirow{2}{*}{$\begin{array}{c}\text { Pipe } \\
\text { without } \\
\text { ethylene } \\
\text { glycol }\end{array}$} \\
\hline & & $\begin{array}{l}\text { Pipe with } \\
\text { ethylene } \\
\text { glycol }\end{array}$ & $\begin{array}{c}\text { Pipe } \\
\text { without } \\
\text { ethylene } \\
\text { glycol }\end{array}$ & $\begin{array}{c}\text { Pipe } \\
\text { with } \\
\text { ethylene } \\
\text { glycol }\end{array}$ & $\begin{array}{l}\text { Pipe } \\
\text { without } \\
\text { ethylene } \\
\text { glycol }\end{array}$ & & \\
\hline \multirow{3}{*}{1} & 50 & 31.5 & 31.5 & 49.7 & 53.2 & 58 & 41 \\
\hline & 100 & 29.1 & 31.5 & 41.7 & 47.6 & 43 & 51 \\
\hline & 150 & 33 & 31.7 & 50.9 & 50.1 & 54 & 58 \\
\hline \multirow{3}{*}{2} & 50 & 25.1 & 32.5 & 52.7 & 63.3 & 110 & 95 \\
\hline & 100 & 25.1 & 32.5 & 60.8 & 59.2 & 142 & 82 \\
\hline & 150 & 33 & 32.5 & 56.3 & 57.8 & 71 & 79 \\
\hline \multirow{3}{*}{3} & 50 & 34.6 & 34.6 & 49.8 & 53.6 & 44 & 55 \\
\hline & 100 & 31.5 & 34.5 & 46.9 & 48.1 & 49 & 39 \\
\hline & 150 & 34.6 & 31.5 & 56.1 & 51.2 & 62 & 63 \\
\hline
\end{tabular}

At depth of $50 \mathrm{~mm}$, the percentage of increment recorded for 3 days for the pipe with ethylene glycol was in range of $44 \%-110 \%$ while at depth $100 \mathrm{~mm}$, the percentage of heat increment recorded was in range of $43 \%-142 \%$. The increment was recorded for the pipe located at $150 \mathrm{~mm}$ from the pavement base was in range of $62 \%-71 \%$. The average percentage for the heat increment of the pipe with ethylene glycol for three days for pipe depth $50 \mathrm{~mm}$ was $71 \%$ while for pipe at depth $100 \mathrm{~mm}$ and $150 \mathrm{~mm}$ was $78 \%$ and $62 \%$ respectively. The percentage increment of the pipe without ethylene glycol for three days for pipe depth $50 \mathrm{~mm}$ was $64 \%$ while for pipe $100 \mathrm{~mm}$ and $150 \mathrm{~mm}$ was $57 \%$ and $67 \%$ respectively.

Not only that, the ethylene glycol effects were more noticeable at the period between 12 to $3 \mathrm{pm}$ where the maximum sun heat radiations are more likely to hit the surface of the pavement. The ethylene glycol also tend to cool faster during night at the pipes located closer to the pavement surface due to the reduction in surrounding temperature which affected the pavement surface at night. It can be conclude that, the ethylene glycol effect was more noticeable compared to the pipe without ethylene glycol.

A significant increment in temperature can be achieved when more heat is applied to the asphalt surface. Thus, the accumulation of heat which causes heat lump can be increase with the performance of asphalt pavement in absorbing heat from radiation.

\subsection{Load bearing capacity of pipe}

The load by the vehicle that passes through the road in daily life would be the effect to the strength of the pavement. The installed pipe in the pavement also can be affected by the loading of the vehicle. Figure 10 shows the maximum load can be supported by the steel pipe at different depth after laboratory testing using California Bearing Ratio (CBR) machine. The load for the AASHTO standard truck for 1 axle was $15.2 \mathrm{kN}$ and for 3 axle was $38.8 \mathrm{kN}$ while for automobile traffic the load was $9.9 \mathrm{kN}$.

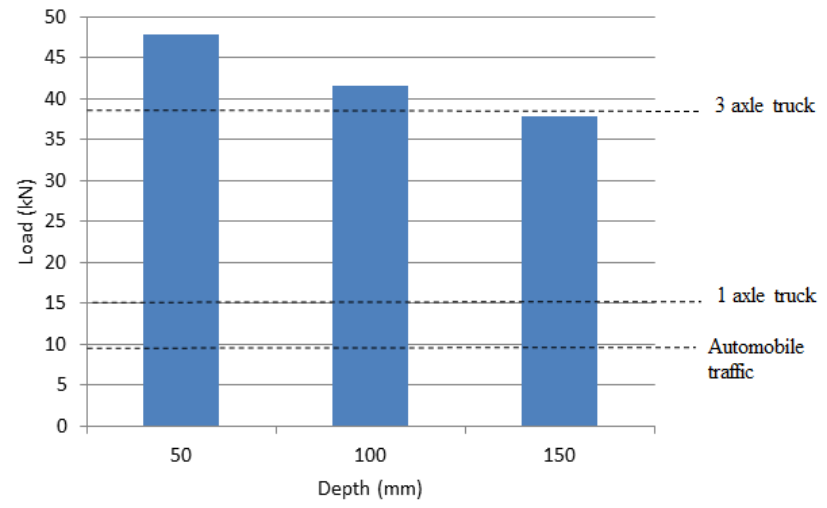

Figure 10 : Strength of steel pipe in different depths 
The data in figure 10 shows that the higher the pipe installed in pavement from pavement base, the lower the maximum load that can sustain on it. At all depths, the pavement can sustain the load for automobile traffic and 1 axle truck but for 3 axle truck, only at depth $150 \mathrm{~mm}$ it cannot support the load. So that it means that pipes must be installed deeper to the pavement to sustain the load that attack on the pavement without considering the load of any vehicle.

\section{Conclusion}

In conclusion, the highest heat that obtained by the ethylene glycol was at depth $150 \mathrm{~mm}$ and the second highest was at depth $50 \mathrm{~mm}$ while the third highest was at depth $100 \mathrm{~mm}$. The pipes located $50 \mathrm{~mm}$ from pavement base have achieved the highest temperature comparing to $100 \mathrm{~mm}$ and $150 \mathrm{~mm}$ while those located $100 \mathrm{~mm}$ above pavement base have achieved the lowest recorded temperature.

Due to the release of storing temperature during night, pipes located $150 \mathrm{~mm}$ from pavement base have recorded the highest temperature as the asphalt layers will release the storing heat to the upper layer of the pavement where $50 \mathrm{~mm}$ pipes were placed. The ethylene glycol effect was more noticeable for the pipes located closer to the pavement surface as the highest average temperature recorded was $51.2^{\circ} \mathrm{C}$ at depth $150 \mathrm{~mm}$. Not only that, the ethylene glycol was also noticed to be more affected at the period between $12 \mathrm{pm}$ to $4 \mathrm{pm}$ where the maximum sun heat radiations are more likely to hit the surface of the pavement. The ethylene glycol also tend to cool faster during night at the pipes located closer to the pavement surface this is due to the reduction in surrounding temperature which affect the pavement surface first at night.

For the strength of pipe, the highest maximum load bearing capacity that can be supported by the stainless steel pipe was at depth $50 \mathrm{~mm}$ and the second highest was at depth $100 \mathrm{~mm}$ while the third highest was at depth $150 \mathrm{~mm}$. So, the suitable depth to install the pipe with the consideration of both cases which was maximum heat gain and the maximum load that can be supported was at depth $50 \mathrm{~mm}$. We choose the second highest temperature for maximum heat and the first highest for the maximum load that can be supported.

\section{Acknowledgement}

The funding for this project were provided by "The Composition and Distribution of Sediment in Sembrong Dam Reservoir by Using Coring and Subbottom Profiling Techniques" (U422), Special Research Contract Grant 2015 (UTHM) and "Green Pemeable Pavement Solar Hybrid Energy Collector" UNITEN Internal Grant 2015. We would also like to offer our sincere thanks to Department of Meteorology Malaysia for the data provided and all Laboratory staff of Faculty of Civil and
Environmental Engineering, UTHM for their continuous cooperation and encouragement.

\section{References}

1. Pascual-Muñoz, P., Castro-Fresno, D., Serrano$\mathrm{Br}$ avo, P., \& Alonso-Estébanez, a. (2013). Thermal and hydraulic analysis of multilayered asphalt pavements as active solar collectors. Applied Energy, 111, 324-332.

2. Solaimanian, M., and Kennedy, T., W., (1993). Predicting maximm pavement surface temperature using maximum air temperature and hourly solar radiation. Transportation Research Record, 1417.

3. Jonathan J. C., (2010). Design and analysis of an embedded pipe network in asphalt pavements to reduce the urban heat island effect. Master of Science in Worcester Polytechnic Institute.

4. Carolyn Roos (2008). Principles of Heat Transfer. The EnergyIdeas Clearinghouse. Energy Efficiency Factsheet. 1- 4.

5. Wang, H., Wu, S., Chen, M., and Zhang, Y., (2010). Numerical simulation on the thermal response of heat-conducting asphalt pavements. Physica Scripta.

6. Wu, S., Chen, M., and Zhang, Y., (2011). Laboratory investigation into thermal response of asphalt pavements as solar collector by application of small scale slabs. Journal of Applied Thermal Engineering, Vol, 31(10), 1582-1587.

7. Liu, X., Xiao, Y., Inthavong, K., and Tu, J., (2015). Experimental and numerical investigation on a new type of heat exchanger in ground source heat pump system. Journal of Energy Efficiency, 1-13.

8. Hasnain. S., M., (2011). Review on sustainable thermal energy storage technologies, Part I: Heat storage materials and techniques. Journal of Energy Conversion and Management. Vol, 39(11), 1127-1138. 